\title{
Physiochemical Analysis of Treated Industrial Effluent Collected from Ahmedabad Mega Pipeline
}

\section{Sweta B Patel ${ }^{1 *}$, Alay Mehta ${ }^{2}$ and Hitesh A Solanki ${ }^{1}$}

${ }^{1}$ Department of Botany, School of Sciences, Gujarat University, Ahmedabad, India

${ }^{2}$ Department of Climate Change, School of Sciences, Gujarat University, Ahmedabad, India

\begin{abstract}
Water is the backbone of all life forms on earth. Water is an essentially important material on earth to both natural ecosystem and human development and for human use. Because of its clear importance, water is the most studied material on earth. Present study deals with physio-chemical analysis of industrial effluent collected from the Ahmedabad mega pipe line. Mega pipeline receives treated effluent of industrial cluster Vatva, Naroda, Odhav and Narol. Mega Pipeline from Naroda to Pirana has carrying capacity of 90 million litre per day (MLD). It is an outlet of Central Effluent Treatment Plant (CETP). Treated effluent is released into Sabarmati River. The study also documents total dissolved solids, calcium hardness, magnesium and Chemical Oxygen Demand exceeding permissible limits.
\end{abstract}

Keywords: Electrical conductivity; Turbidity; Salinity

\section{Introduction}

Water is an essential abiotic component for life forms. Sustainability of an ecosystem depends upon water. Water resources are of critical importance to both natural ecosystem and human development and for human use. Good quality of water resources depends on a large number of physicochemical parameters and biological characteristics. Rivers are a rich source of water supply for irrigation, drinking, hydroelectric power generation and fish culture. The water of the reservoir should fulfill the quality required for human use as well as for the sustainability of the ecology. Ecosystem services supply is their capacity to provide this specific service within a given time period. This supply is linked to the rate of generation of the ecosystem, which is determinate by environmental resources and human contributions interfere with ecosystem services [1].

Industrialization is considered the cornerstone of development strategies due to its significant contribution to the economic growth and human welfare, but it carries inevitable costs and problems in terms of pollution of the air and water resources. Specially waterbodies are getting polluted due to effluent discharge [2]. Effluents are primary threats to the native biodiversity in fresh waters [3-5]. Industrial effluents are threats to the river system and hydrology of the ecosystem. Effluent discharge leads to changes in community structure and community composition. Many times these effluents are composed of heavy metals which may further lead to bioaccumulation issue [6]. Effluents discharged in waterbodies changes the nutrient composition which has harmful effect on aquatic life [7]. Variations of water quality is an indicators which helps to evaluate the influence of urban land use activities [8]. Rivers are traditional as water resource, they do provide habitat for flora and fauna. River flow affects population and community of both flora and fauna [9]. Effulents cause bioaccumulation [10]. Effluent exceeding permissible limits do harm flora and fauna componants.

Present study shows water status of treated effluent released by megapipe line. The treated effluent is released into the river, which is used for agriculture and other purpose.

\section{Materials and Methods}

\section{Study area}

Ahmedabad Mega pipeline is situated at $22^{\circ} 58^{\prime} 53.42^{\prime \prime} \mathrm{N}$ and $72^{\circ} 32^{\prime} 33.71^{\prime \prime}$ E near Gyaspur Village. Mega pipeline is $27 \mathrm{kms}$ long and receives treated effluent of industrial cluster Vatva, Naroda, Odhav and Narol. Mega Pipeline from Naroda to Pirana has carrying capacity of 90 MLD. It is an outlet of Central Effluent Treatment Plant (CETP). Earlier there was a direct discharge of effluent by industrial units into Khari cut canal. But there is no direct discharge of effluent into Khari cut canal after High Court directives and subsequent vigilante actions by GPCB. Individual industrial units have provided Primary effluent treatment plants. Treated wastewater is discharged into CETP. The treated effluent from CETPs is discharged into Mega pipeline (Figures 1 and 2) [11].

\section{Sampling}

Water sample has been collected from outlet of pipe. Initially the prewashed bottles were rinsed with sample water. The closed bottle was dipped at the depth of 0.5 to $0.7 \mathrm{~m}$. and then a bottle was opened inside and was folded again to take it out at the open. The samples were gathered up from five different points and were amalgamated together to make an integrated sample.

\section{Physiochemical analysis}

Temperature, $\mathrm{pH}$, electrical conductivity, turbidity, salinity, total dissolved solids, chloride, total hardness, calcium hardness, magnesium, alkalinity, acidity, dissolved oxygen, nitrate, sodium, phosphate, biological oxygen demand, chemical oxygen demand has been assessed for physiochemical analysis of water. Standard Methods for the Examination of Water and Wastewater (Standard Methods), $19^{\text {th }}$ edition, APHA, AWWA, WEF, 1995 were used for analysis of water samples. Results are compared with standards given by the Central Pollution Control Board.

*Corresponding author: Sweta B Patel, Research Scholar, Department of Botany, School of Sciences, Gujarat University, Ahmedabad, India, Tel: 07926301341; E-mail: swetapatel93.sp@gmail.com

Received July 12, 2017; Accepted August 03, 2017; Published August 09, 2017

Citation: Patel SB, Mehta A, Solanki HA (2017) Physiochemical Analysis of Treated Industrial Effluent Collected from Ahmedabad Mega Pipeline. J Environ Anal Toxicol 7: 497. doi: 10.4172/2161-0525.1000497

Copyright: @ 2017 Patel SB, et al. This is an open-access article distributed under the terms of the Creative Commons Attribution License, which permits unrestricted use, distribution, and reproduction in any medium, provided the original author and source are credited. 
Citation: Patel SB, Mehta A, Solanki HA (2017) Physiochemical Analysis of Treated Industrial Effluent Collected from Ahmedabad Mega Pipeline. J Environ Anal Toxicol 7: 497. doi: 10.4172/2161-0525.1000497

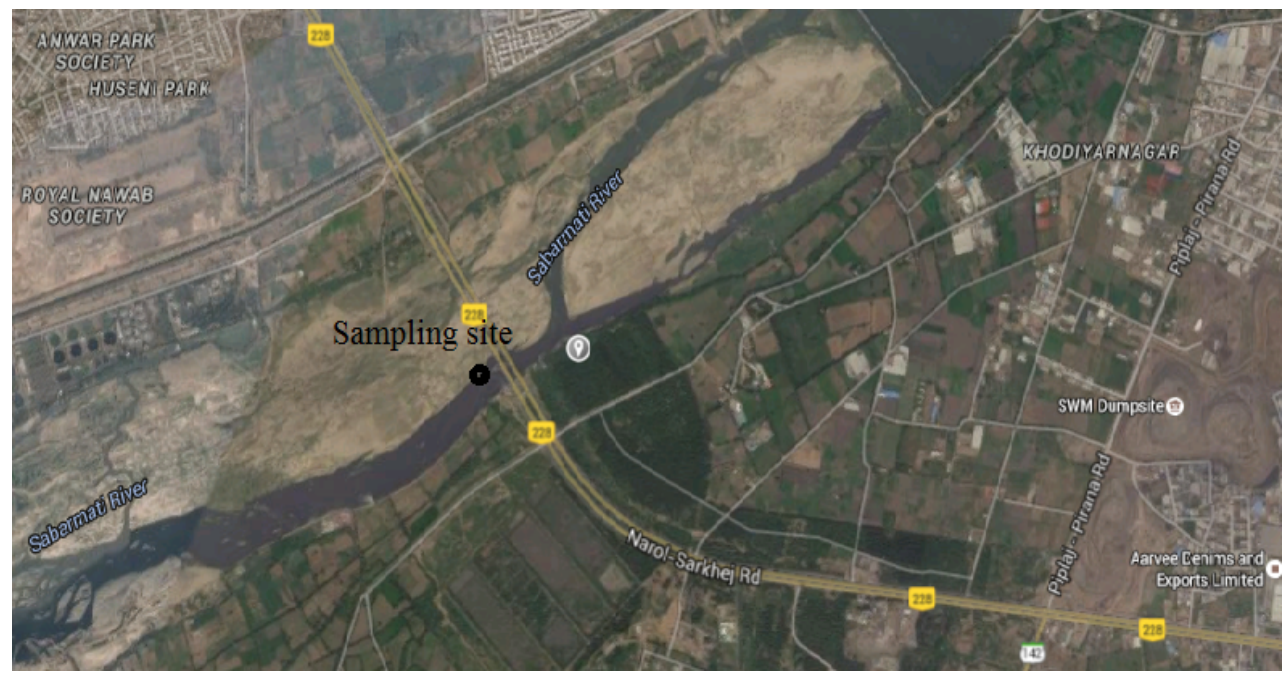

Figure 1: Mega pipeline, Gyaspur village, Ahmedabad.

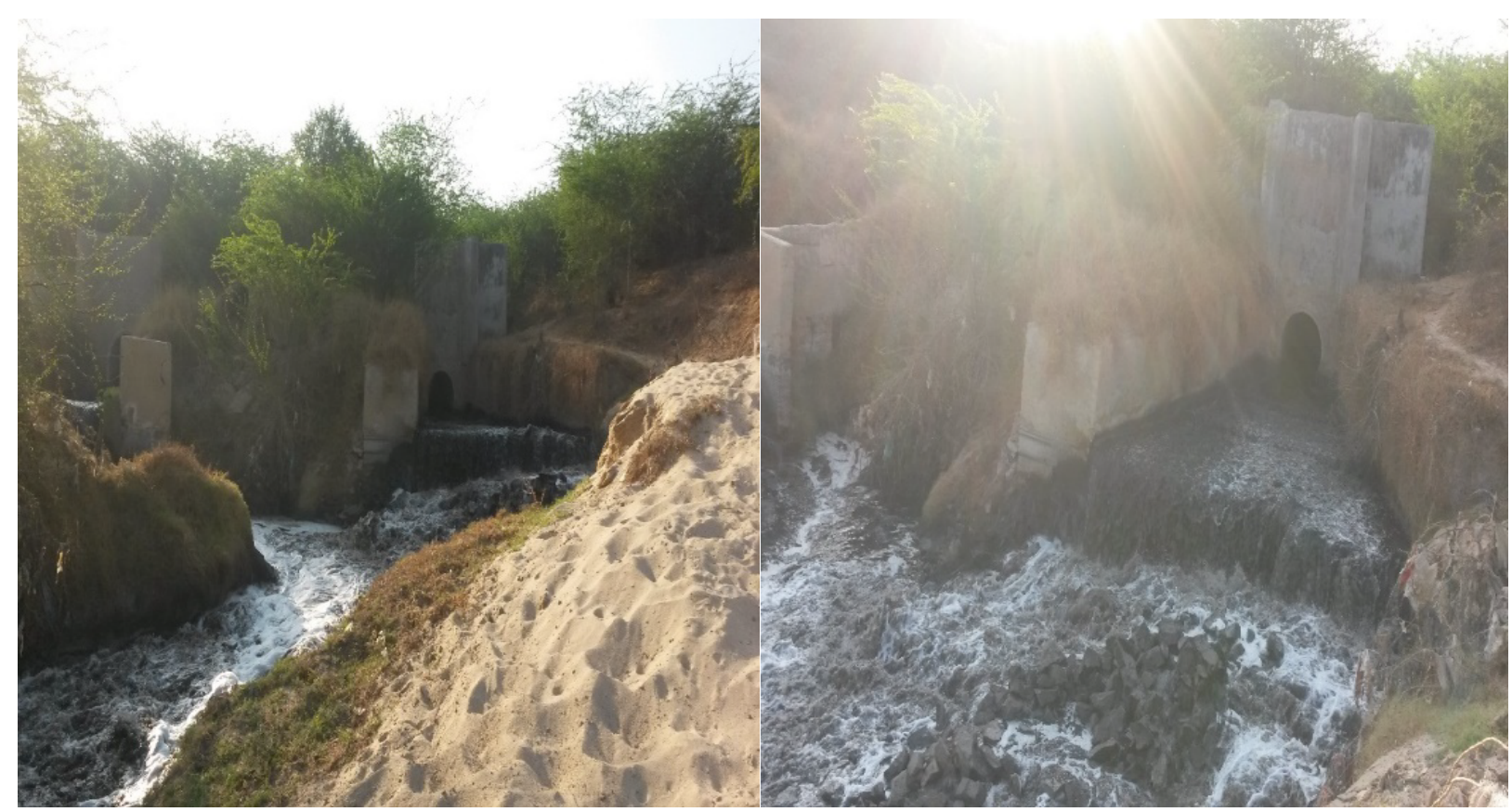

Figure 2: Effluent discharge at mega pipeline.

\section{Results and Discussion}

\section{Temperature}

Temperature plays an important role in controlling other physicochemical and biological parameters of water. It plays an essential role in water quality and also influences the aquatic enviornment [12]. As water temperature rises, the rate of photosynthesis increases, providing there adequate amounts of nutrients [13]. It affects production rate and growth rate of various aquatic bacteria and production of algal biomass in fresh water as well as marine water [14]. Water temperature should be accounted for when determining; metabolic rates and photosynthesis production, compound toxicity, dissolved oxygen and other dissolved gas concentrations, conductivity and salinity, oxidation reduction potential (ORP), pH, water density [15].
In present study temperature of treated effluent was $21.6^{\circ} \mathrm{C}$. Standard permissible limit of effluent temperature is $45^{\circ} \mathrm{C}$. Thus, temperature is within permissible limit which is ideal for aquatic ecosystem (Figure 3 ).

\section{$\mathrm{pH}$}

$\mathrm{pH}$ is the scale of intensity of acidity and alkalinity of water. It measures the concentration of hydrogen ions. $\mathrm{pH}$ determines life of aquatic plant and organism living inside water. They are affected by $\mathrm{pH}$ because most of their metabolic activities are $\mathrm{pH}$ dependent [16]. $\mathrm{pH}$ can also affect the solubility and toxicity of chemicals and heavy metals in the water. Even minor $\mathrm{pH}$ changes can have long-term effects. $\mathrm{pH}$ of treted effluent was 6.14 which was more than permissible limit of industrial effluents. Optimal $\mathrm{pH}$ range for sustainable aquatic life is $\mathrm{pH}$ 6.5-8.2 [17]. $\mathrm{pH}$ of effluents was less than optimal $\mathrm{pH}$ range which 
Citation: Patel SB, Mehta A, Solanki HA (2017) Physiochemical Analysis of Treated Industrial Effluent Collected from Ahmedabad Mega Pipeline. J Environ Anal Toxicol 7: 497. doi: 10.4172/2161-0525.1000497

Page 3 of 6

can be harmful for aquatic flora and fauna where effluents are released (Figure 4).

\section{Electrical conductivity}

Electrical conductivity is a measurement of the ability of an aqueous solution to carry an electrical current. This ability is directly related to the concentration of ions in the water. Electrical conductivity of water is a useful and easy indicator of its salinity or total salt content. Wastewater effluents often contain high amounts of dissolved salts from domestic sewage and industrial waste [18]. EC in effluent was 2.6 $\mu \mathrm{S}$. Higher EC value can have adverse effect on aquatic environment.

\section{Turbidity}

Turbidity is a measure of cloudiness and haziness due to suspended solids which are invisible with naked eyes. High concentrations of particulate matter affect light penetration and productivity, recreational values, and habitat quality [19]. Particles also provide attachment places for other pollutants, notably metals and bacteria. For this reason, turbidity readings can be used as an indicator of potential pollution in a water body [20] (Figure 5). Treated effluent was semitransparent with 21.3 NTU turbidity. It was under permissible limit. Turbidity shows pollution and accumulation of particles at some what extent (Table 1).

\section{Salinity}

Salinity is the measure of all the salts dissolved in water. Salinity determine nature and composition of aquatic ecosystem. Some organism adapted to low saline water, whereas some are holophytic in nature [21]. Salinity of effluent was $204 \mathrm{mg} / \mathrm{L}$.

\section{Total dissolved solids}

Total dissolved solid (TDS) is a measurement of inorganic salts, organic matter and other dissolved materials in the water [22]. Total dissolved solids cause toxicity through increases in salinity, changes in the ionic composition of the water and toxicity of individual ions. Total dissolved solids are an extremely important cause of water quality deterioration leading to aesthetic issues, a decline in the fisheries resource, and serious ecological degradation of aquatic environments [23]. Total dissolved solids of effluents were $2347.23 \mathrm{mg} / \mathrm{L}$. TDS were above the permissible limit which is $2100 \mathrm{mg} / \mathrm{L}$. Higher level of TDS decrease light penetration in water which leads to low productivity of ecosystem (Figure 6) [19].

\section{Chloride}

Chloride content in water plays a vital role in water quality as the accumulation and persistence of chloride poses a risk to the water quality and the plants, animals, and humans who depend upon it [24]. Chloride in surface waters can be toxic to many forms of aquatic life [25]. Chloride concentration in effluent was $487.94 \mathrm{mg} / \mathrm{L}$ (Figure 7).

\section{Total hardness}

Total hardness of water is not a specific constituent but is a variable and complex mixture of cations and anions. In water, the principle hardness causing ions are calcium and magnesium. Thus, Water hardness is the amount of dissolved calcium and magnesium in the water. Hard water is high in dissolved minerals, both calcium and magnesium [26]. Total hardness of effluent was $599.32 \mathrm{mg} / \mathrm{L}$. Total hardness, especially $\mathrm{Ca}^{2+}$ hardness, is a well-known modifying factor of toxicity of heavy metals and other chemicals. High level of water hardness cause toxic effects on fish and shrimp populations. It affects hatching, egg size, larval survival, mortality rate, etc. [27]. High levels of waterborne $\mathrm{Mg}^{2+}$ or $\mathrm{Ca}^{2+}$ can lead to hypocalcemia or hypercalcemia, respectively [28].

\section{Calcium hardness}

Calcium hardness shows calcium content in water. Calcium content directly affects total hardness of water. Calcium hardness of collected effluent was $127.84 \mathrm{mg} / \mathrm{L}$ which was above permissible limit. High calcium level in water often leads to hypercalcemia in aquatic organisms (Figure 8) [28].

\section{Magnesium}

Magnesium is often associated with calcium in all kinds of waters, but its concentration remains generally lower than the calcium. Magnesium is essential for chlorophyll growth and it also acts as a limiting factor for the growth of phytoplankton [29]. Magnesium level in water also affects aquatic fauna like fish, shrimps etc. by contributing in total hardness [27]. Magnesium in collected effluent was 144.55 $\mathrm{mg} / \mathrm{L}$. It was above permissible limit which is $100 \mathrm{mg} / \mathrm{L}$. Here in this case magnesium content in water is higher than calcium which is unusual (Figure 9).

\begin{tabular}{|c|c|c|c|}
\hline S. No. & Parameters & Average with standard error value & Standard permissible limit of industrial effluent \\
\hline 1 & Temperature $\left({ }^{\circ} \mathrm{C}\right)$ & $21.6 \pm 0.3333$ & 45 \\
\hline 2 & $\mathrm{pH}$ & $6.14 \pm 0.0120$ & $5.5-9$ \\
\hline 3 & $\mathrm{EC}(\mu \mathrm{S})$ & $2.06 \pm 0.0066$ & _ \\
\hline 4 & Turbidity (NTU) & $21.3 \pm 0.1763$ & 300 \\
\hline 5 & Salinity (mg/L) & $2.4 \pm 0.0333$ & _- \\
\hline 6 & TDS (mg/L) & $2347.23 \pm 0.1189$ & 2100 \\
\hline 7 & Chloride (mg/L) & $487.94 \pm 0.0305$ & 1000 \\
\hline 8 & Total hardness (mg/L) & $599.32 \pm 0.0185$ & _ \\
\hline 9 & Calcium hardness (mg/L) & $127.84 \pm 0.0057$ & 100 \\
\hline 10 & Magnesium (mg/L) & $144.55 \pm 0.0057$ & 100 \\
\hline 11 & Alkalinity (mg/L) & $815.33 \pm 0.2848$ & - \\
\hline 12 & $\mathrm{DO}(\mathrm{mg} / \mathrm{L})$ & $2563.17 \pm 0.0185$ & - \\
\hline 13 & Nitrate $(\mathrm{mg} / \mathrm{L})$ & $30.09 \pm 0.0480$ & - \\
\hline 14 & Sodium (mg/L) & $406.03 \pm 0.0317$ & _ \\
\hline 15 & Phosphate (mg/L) & $2.66 \pm 0.1452$ & 5 \\
\hline 16 & $\mathrm{BOD}(\mathrm{mg} / \mathrm{L})$ & $268.05 \pm 0.0348$ & 350 \\
\hline 17 & COD (mg/L) & $1595.71 \pm 0.3609$ & 100 \\
\hline
\end{tabular}

Table 1: Average with standard error values of physicochemical parameters. 


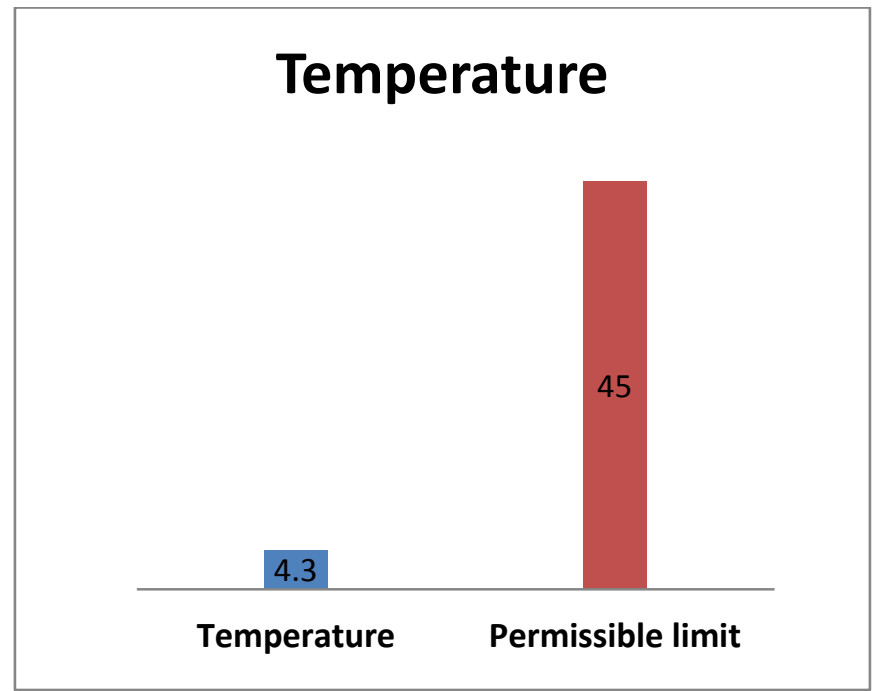

Figure 3: Temperature.

\section{Turbidity (NTU)}

21.3

Turbidity Permissible limit

Figure 5: Turbidity.

\section{Chloride (mg/L)}

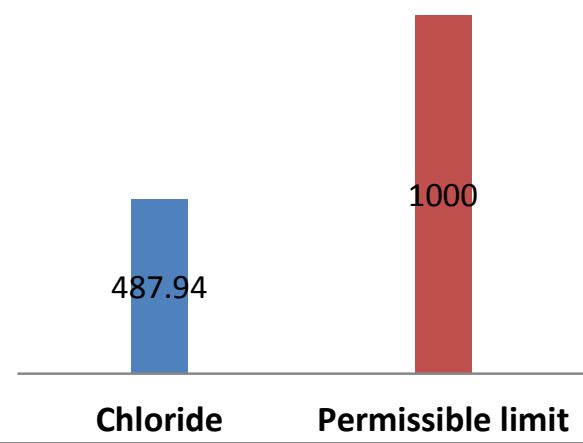

Figure 7: Chloride.

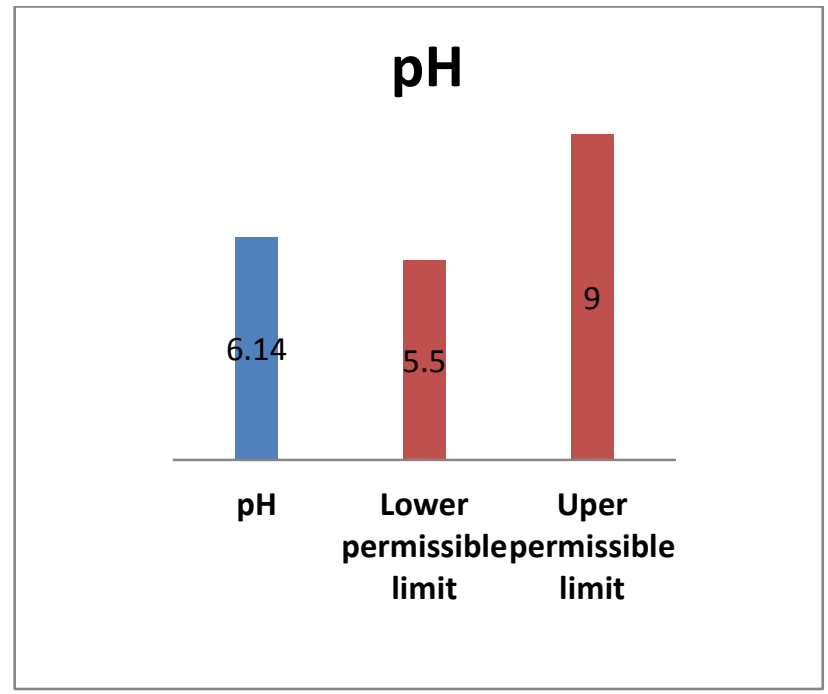

Figure 4: $\mathrm{pH}$.

\section{$\operatorname{TDS}(\mathrm{mg} / \mathrm{L})$}

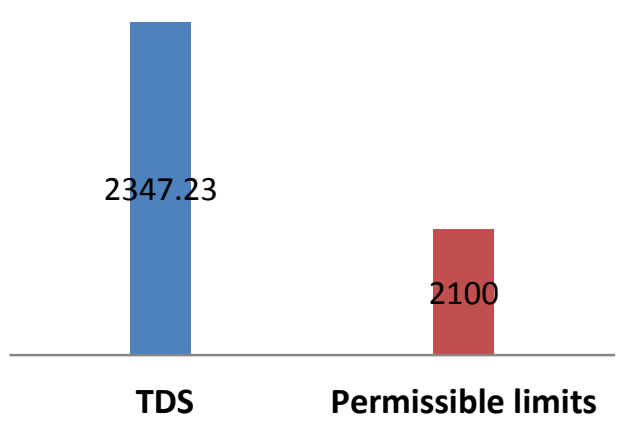

Figure 6: Total dissolved Solid.

\section{Ca Hardness (mg/L)}

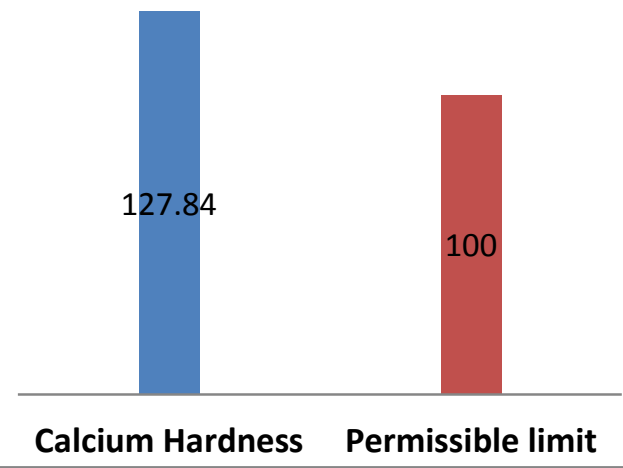

Figure 8: Calcium Hardness. 
Citation: Patel SB, Mehta A, Solanki HA (2017) Physiochemical Analysis of Treated Industrial Effluent Collected from Ahmedabad Mega Pipeline. J Environ Anal Toxicol 7: 497. doi: 10.4172/2161-0525.1000497

Page 5 of 6

\section{Alkalinity}

Alkalinity is a measure of capacity of water to neutralize a strong acid [30]. Alkalinity of water is directly related to $\mathrm{pH}$. Thus, minor variation in alkalinity leads to changes in $\mathrm{pH}$ causes diverse effect on aquatic flora and fauna leading. Alkalinity of effluent was $815.33 \mathrm{mg} / \mathrm{L}$.

\section{Dissolved oxygen}

Measurement of dissolved oxygen is a primary parameter in all pollution studies. Dissolved oxygen refers to the level of free, noncompound oxygen present in water or other liquids. It is an important parameter in assessing water quality because of its influence on the organisms living within a body of water [31]. A dissolved oxygen level that is too high or too low can harm aquatic life and affect water quality. When the DO drops below a certain level, the life forms in that water are unable to continue at a normal rate [32]. DO is related to temperature, as temperature rises DO is decreases or vice-versa [15]. High COD levels decrease the amount of dissolved oxygen available for aquatic organisms [33]. Here dissolved oxygen level was $2563.17 \mathrm{mg} / \mathrm{L}$.
Nitrate

Nitrate in surface water is an important factor for water quality assessment [34]. Industrial effluents contains high amount of nitrate. Nitrate content recorded was $30.09 \mathrm{mg} / \mathrm{L}$.

\section{Sodium}

Sodium in water plays important role in water quality as sodium along with chloride creates higher water density [35]. Sodium content in effluent was $406.03 \mathrm{mg} / \mathrm{L}$.

\section{Phosphate}

Phosphate is a generic term for the oxy-anions of phosphorus. Enrichment of water with orgnic phosphates and nitrate results in an excessive growth of plants and other micro-organisms [29]. Phosphate found in effluent was $2.66 \mathrm{mg} / \mathrm{L}$ (Figure 10).

\section{Biological oxygen demand}

Biolgical Oxygen Demand test is the most widely used parameter of

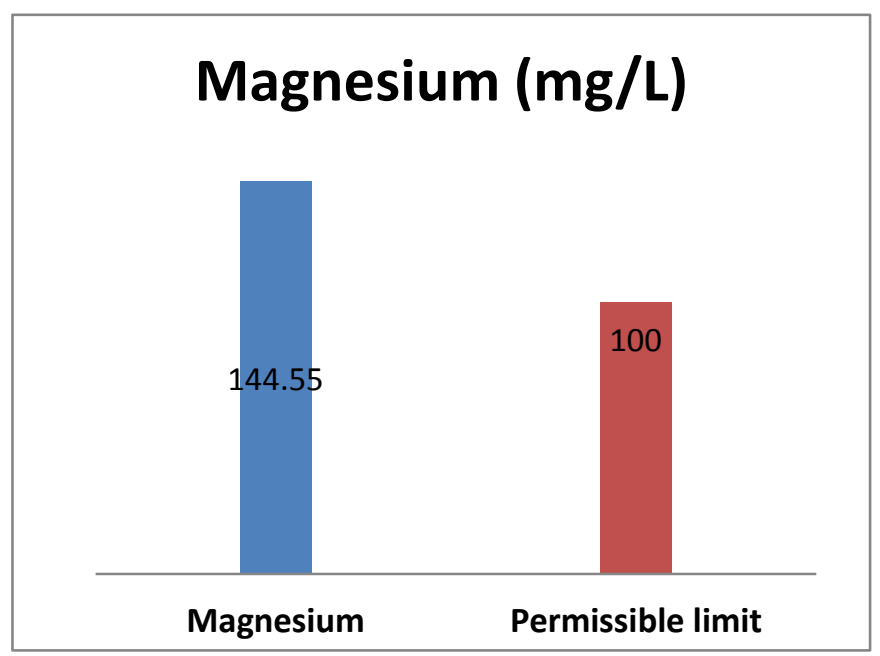

Figure 9: Magnesium.

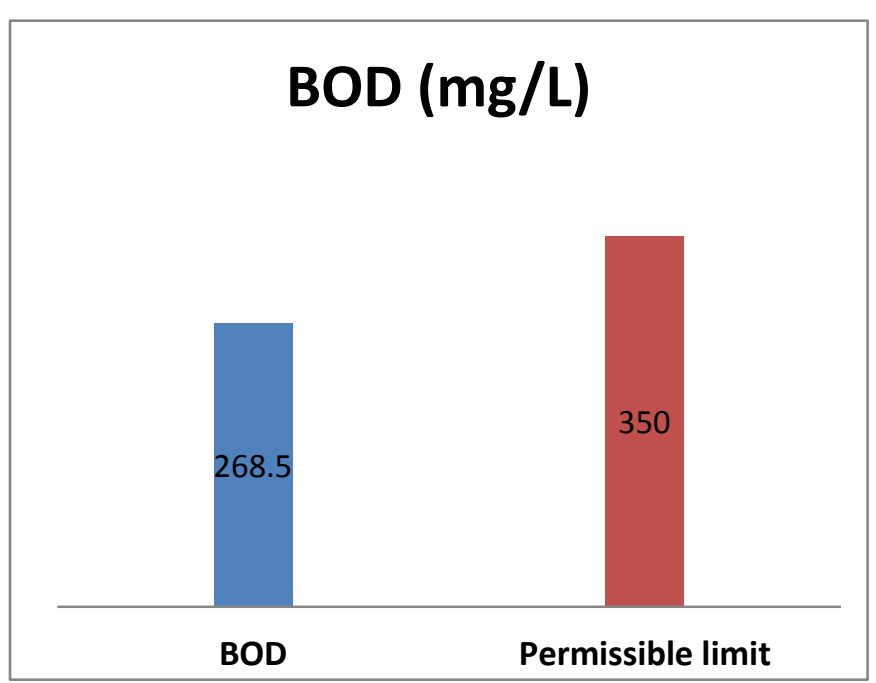

Figure 11: Biological Oxygen Demand.

\section{Phosphate (mg/L)}

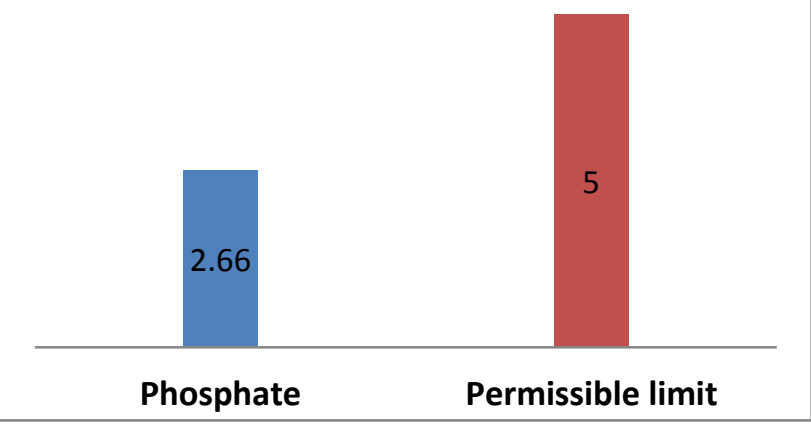

Figure 10: Phosphate.

\section{$\operatorname{COD}(\mathrm{mg} / \mathrm{L})$}

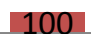

COD

Permissible limit

Figure 12: Chemical Oxygen Demand. 
Citation: Patel SB, Mehta A, Solanki HA (2017) Physiochemical Analysis of Treated Industrial Effluent Collected from Ahmedabad Mega Pipeline. J Environ Anal Toxicol 7: 497. doi: 10.4172/2161-0525.1000497

Page 6 of 6

water analysis. The BOD is may be defined as the oxygen required for the microorganism to carry out biological decomposition of dissolved solids or organic matter in the wastewater under aerobic conditions at standard. Therefore, with increase in the amount of organic matter in the water the BOD increases. BOD is one of the most common measures of pollutant organic material in water [29]. BOD of collected effluent recorded $268.05 \mathrm{mg} / \mathrm{L}$. it is within permissible limit which is $350 \mathrm{mg} / \mathrm{L}$. It indicated low amount of organic matter in effluent (Figure $11)$.

\section{Chemical oxygen demand}

Chemical Oxygen Demand determine available dissolved oxygen in water. High COD levels decrease the amount of dissolved oxygen available for aquatic organisms [32]. COD of collected effluent found very high which was $1595.71 \mathrm{mg} / \mathrm{L}$. It is above permissible limit. Permissible limit of COD is $100 \mathrm{mg} / \mathrm{L}$. High level of COD indicates low amount of dissolved oxygen available which has adverse effect on aquatic flora and fauna (Figure 12) [36].

\section{Conclusion}

Physiochemical analysis of water quality in treated industrial effluent collected from Ahmedabad mega pipeline were invesitigated. The present study reveals that total dissolved solids, calcium hardness, magnesium and chemical oxygen demand is above permissible limit given by Gujarat Pollution Control Board and Central Pollution Control Board which may be harmful to the ecosystem. This treated effluents released directly into the Sabarmati River which may drastically affect aquatic organism growth in the river. There is an urgent requirement of planning by the civic body to combat the pollution rate in River. This initiative will help in sustaining the ecology and aquatic life in the Sabarmati River.

\section{References}

1. Kroll F, Muller F, Haase D, Fohrer N (2012) Rural-Urban gradient analysis of ecosystem services supply and demand dynamics. Land Use Policy 29: 521535 .

2. Kannj I, Achi O (2011) Industrial Effluents and their impact on water quality of receiving rivers in Nigeria. Journal of Applied Technology in Environmental Sanitation 1: 75-86.

3. Sala OE, Chapin FS, Armesto JJ, Berlow R, Bloomfield J, et al. (2000) Global Biodiversity Scenarios for the Year 2100. Science 287: 1770-1774.

4. Agostinho AA, Thomaz SM, Gomes LC (2005) Conservation of the biodiversity of Brazil's inland waters. Conserv Biol 19: 646-652.

5. Dudgeon D, Arthington AH, Gessner MO, Kawabata ZI, Knowler DJ, et al. (2006) Freshwater Biodiversity: Importance, Threats, Status and Conservation Challenges. Biological Reviews 81: 163-182.

6. Kennish MJ (2014) Environmental threats and environmental future of estuaries. Environmental Conservation 29: 78-107

7. Mdamo A (2001) Accumulation of Nutrients and Heavy Metals in plants at Kagondo natural Wetland.

8. Okeke PN, Adina EN (2013) Water Quality Study of Ontamiri River in Owerri, Nigeria. Universal Journal of Environmental Research and Technology 3: 641649 .

9. Anderson KE, Paul AJ, McCauley E, Jackson LJ, Post JR, et al. (2006) Instream flow needs in streams and rivers: the importance of understanding ecological dynamics. Frontiers in Ecology and the Environment 4: 309-318.

10. Van der Oost R, Beyer J, Vermeulen NP (2003) Fish bioaccumulation and biomarkers in environmental risk assessment: a review. Environmental Toxicology and Pharmacology 13: 57-149.

11. Gujarat Pollution Control Board (2010).
12. Singh RP, Mathur $P$ (2005) Investigation of variations in physicochemical characteristics of a fresh water reservoir of Ajmer city, Rajesthan. Ind J Environ Sci 9: 57-61.

13. Poole P, Geoffrey C, Berman CH (2001) An Ecological Perspective on Instream Temperature: Natural Heat Dynamics and Mechanisms of Humancaused Thermal Degradation. Environmental Management 27: 787-802.

14. White PA, Kalff J, Rasmussen JB, Gasol JM (1991) The effect of temperature and algal biomass on bacterial production and specific growth rate in freshwater and marine habitats. Microbial ecology 21: 99-118.

15. Wilde F (2006) Temperature 6.1. In USGS Field Manual. Retrieved from http:// water.usgs.gov/owq/FieldManual/Chapter6/6.1_ver2.pdf

16. Wang W, Wang A, Chen L, Liu Y, Sun R (2002) Effects of pH on Survival, Phosphorus Concentration, Adenylate Energy Charge and $\mathrm{Na}^{+}-\mathrm{K}^{+}$ATPase Activities of Penaeus chinensis Osbeck Juveniles. Aquatic Toxicology 60: 7583.

17. Murdoch T, Cheo M, O'Laughlin K (2001) Streamkeeper's Field Guide Watershed Inventory and Stream Monitoring Methods. Adopt-A-Stream Foundation, Everett, WA, p: 297.

18. Morrison G, Fatoki OS, Persson L, Ekberg A (2001) Assessment of the impact of point source pollution from the Keiskammahoek Sewage Treatment Plant on the Keiskamma River-pH, electrical conductivity, oxygen-demanding substance (COD) and nutrients. Water Sa 27: 475-480.

19. Lloyd, Denby S (1987) Turbidity as a water quality standard for salmonid habitats in Alaska. North American journal of fisheries management 7: 34-45.

20. Swanson HA, Baldwin HL (1965) A Primer on Water Quality. US Geological Survey.

21. Nielsen DL, Brock MA, Rees GN, Baldwin DS (2003) Effects of increasing salinity on freshwater ecosystems in Australia. Australian Journal of Botany 51 : $655-665$.

22. US Environmental Protection Agency (1986).

23. Bilotta GS, Brazier RE (2008) Understanding the influence of suspended solids on water quality and aquatic biota. Water research 42: 2849-2861.

24. US Environmental Protection Agency (1988).

25. Wilcox DA (1986) The effects of deicing salts on vegetation in Pinhook Bog Indiana. Canadian Journal of Botany 64: 865-874.

26. US Geological Survey (2013)

27. Luo S, Wu B, Xiong X, Wang J (2016) Effects of Total Hardness and Calcium:Magnesium Ratio of Water during Early Stages of Rare Minnows (Gobiocypris rarus) Comparative Medicine 66: 181-187.

28. Wendelar Bonga SE, Löwik CJ, van der Meij JC (1983) Effects of external $\mathrm{Mg}^{2+}$ and $\mathrm{Ca}^{2+}$ on branchial osmotic water permeability and prolactin secretion in the teleost fish Sarotherodon mossambicun. Gen Comp Endocrinol 52: 222-231.

29. Qureshimatva UM, Solanki HA (2015) Physico Chemical Parameters of water in Bibi Lake, Ahmedabad, Gujarat, India. Journal of Pollution Effects \& Control p: 3

30. Wetzel RG (1983) Limnology. 2nd edn. Wetzel LG (ed.), Michigan State University, CRS College Publishing Philadelphia, New York, USA.

31. Smitha AD, Shivashankar $P$ (2013) Physico-chemical analysis of the freshwater at river Kapila, Nanjangudu industrial area, Mysore, India. International Research Journal of Environment Sciences 2: 59-65.

32. Wetzel RG (2001) Limnology; lake and River Ecosystem 3rd edn. Academic Press New York, p: 1006.

33. US Environment Protection Act (2010).

34. Jones PJ, Burt TP (1993) Nitrate in surface water. In Nitrate: process, patterns and management cedes. John Wiley, pp: 269-310.

35. New Hempshire Department of Environmental Services (2007) Hazard Identification for Human and Ecological Effects of Sodium Chloride Road Salt.

36. Science for Environment Policy (2015) Ecosystem Services and the Environment. In-depth Report 11 produced for the European Commission, DG Environment by the Science Communication Unit. 